\title{
低温遭遇期間と時期がトルコギキョウの覆輪発現に及ぼす影響
}

\author{
渡辺 功 $^{\mathrm{a}}$ \\ 熊本県農業研究センター 861-1113 熊本県合志市栄 3801
}

\section{Influence of Low Temperature Treatment on Petal Color of Picotee Cultivar of Eustoma grandiflorum}

\author{
Isao Watanabe ${ }^{\mathrm{a}}$ \\ Kumamoto Prefectural Agricultural Research Center, Koushi, Kumamoto 861-1113
}

\begin{abstract}
Artificial climate experiments were conducted to evaluate the effects of timing and period of low temperature treatment on petal coloring of picotee cultivar of Eustoma grandiflorum. After pistil formation of the first flower bud, low temperature treatment was carried out with the daytime temperature set at $20^{\circ} \mathrm{C}$ and the night temperature set at $15^{\circ} \mathrm{C}$. The coloration rate of the petal increased with increases in the duration of low temperature treatment up to 6 weeks. And the coloration rate increased when low temperature treatment was started as soon as the pistil formation stage of the first flower bud. However, if daytime temperature was set at $30^{\circ} \mathrm{C}$ and the night temperature was set at $15^{\circ} \mathrm{C}$ during the 4 weeks after pistil formation of the first flower bud, the colored area of the petal was more than $40 \%$ in $0-2.9 \%$ of the flowers. In this case, the quality of cut flower was superior to the quality of cut flowers grown at consistently high temperatures throughout cultivation. Furthermore, the possibility that another factor besides the developmental stage of the flower bud participated in this phenomenon was suggested by the increasing petal coloration rate at low temperatures.
\end{abstract}

Key Words : coloration rate of the petal, petal formation, pistil formation

キーワード : 花弁形成, 花弁の着色割合, 雌ずい形成

\section{緒言}

トルコギキョウには，一代雑種育種法によって育成され た様々な花色と花形の一重と八重の品種がある（山口, 1991). なかでも, 純白の花弁に紫やピンクの縁取りのある 覆輪品種の花は, そのコントラストが美しく, 可憐さから トルコギキョウの魅力を一層際立たせている。しかし，こ の覆輪は, 採花時期によって第 1 図のように花弁の着色割 合の異なる花弁が生じることが知られている(渡辺, 2006). 特に，口ゼットを回避する育苗方法 (吾妻・高野, 1996; 大 川ら，1996）が開発されたことで可能になった冬期採花の 作型に打いて覆輪発現の乱れが顕著になり, 着色割合の高 い花弁が多発して問題になっている（渡辺，2006）.

渡辺（2006）は, 覆輪の 2 品種を周年的に栽培し, 採花 日から遡った 60 日間の $20^{\circ} \mathrm{C}$ 未満の積算遭遇時間と花弁の 着色割合が正の相関関係にあり, $20^{\circ} \mathrm{C}$ 未満の積算遭遇時間 が 800 時間を上回ると花弁の着色割合が直線的に高まるこ とを報告している. 福田ら（2005）は， $25^{\circ} \mathrm{C}$ 一定条件で,

2008 年 12 月 12 日 受付. 2009 年 6 月 16 日 受理.

E-mail: watanabe-i-dz@pref.kumamoto.lg.jp

a 現在:熊本県菊池地域振興局農林部 熊本県菊池市隈府 1272-10
覆輪の発現は正常であるが, $20^{\circ} \mathrm{C}$ 一定条件下で多くの品種 の覆輪発現が乱れることを報告している。しかし，これま でに $20^{\circ} \mathrm{C}$ 以下の低温の遭遇期間や時期と覆輪発現との関係 について調べた報告はない，一方，渡辺（2000）は，昼温 が $28 \sim 30^{\circ} \mathrm{C}$ の高温であれば，夜温が $10 \sim 15^{\circ} \mathrm{C}$ の低温で 栽培してもトルコギキョウの覆輪発現は乱れないことを報 告している．福田・中山（2008）も，鉢上げ 4 週後〜開花 まで $20^{\circ} \mathrm{C}$ を基点とした日較差が主茥の頂花である第 1 花の 覆輪発現に及ぼす影響を調査し, 昼温が $35^{\circ} \mathrm{C}$ の高温であれ

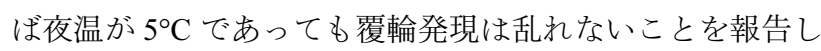
ている. これらの報告は, 昼温が $20^{\circ} \mathrm{C}$ であれば夜温が 15 〜 $20^{\circ} \mathrm{C}$ の比較的高温であっても覆輪発現の乱れが顕著であ り, 昼温が $28 \sim 30^{\circ} \mathrm{C}$ の高温であれば, 夜温が $10 \sim 15^{\circ} \mathrm{C}$ の比較的低温であっても覆輪発現は乱れないことを示して いる. 生産現場では, 暖房機で冬期の夜温を $13 \sim 20^{\circ} \mathrm{C} に$ 管理している（速水，2003; 諸富, 2003; 渡辺，2003）。 そこ で，本報では，生産現場の現状に合わせて，覆輪発現の乱 れが生じる低温を昼温 $20^{\circ} \mathrm{C}$ 夜温 $15^{\circ} \mathrm{C}$ に, 覆輪発現の乱れ が生じない高温を昼温 $30^{\circ} \mathrm{C}$ 夜温 $15^{\circ} \mathrm{C}$ に設定して，第 1 花 の䧳ずい形成期を起点として㡺温 $20^{\circ} \mathrm{C}$ 夜温 $15^{\circ} \mathrm{C}$ へ遭遇 期間と時期が第 1 花だけではなく, 商品として重要な上位 の次数の小花の覆輪発現に及ぼす影響について検討した. 


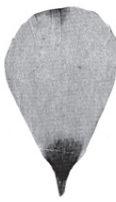

$3 \%=$

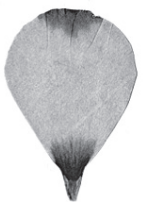

$9 \%$

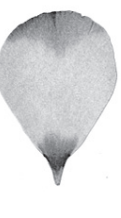

$20 \%$

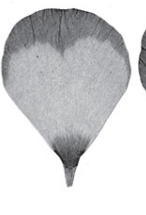

$32 \%$

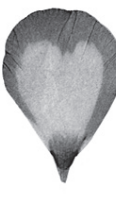

$49 \%$



$100 \%$
第 1 図花弁の着色状況と割合

z 花弁下段は花弁の着色割合

\section{材料および方法}

\section{1. 栽培概要と試験区の構成}

供試品種として, 土壌病害に強く, 渡辺（2000）の試験 に打いて低温下で覆輪発現の乱れが顕著であり, 着色割合 の高い花弁が高頻度で生じたピンクの覆輪の ‘メロウロー ズピコ’（タキイ種苗（株））を用いた。 2002 年 8 月 13 日 に播種し，午後 4 時〜午前 8 時まで $14^{\circ} \mathrm{C}$ で夜冷育苗した. 粘質土壌と育苗用培養土（W. R. Grace 製，メトロミックス 350）を 1:1の体積比で混合した配合土を縦 $26 \mathrm{~cm} \times$ 横 $56 \mathrm{~cm} \times$ 深さ $18 \mathrm{~cm}$ のコンテナに充填し, $9 \mathrm{~cm} \times 9 \mathrm{~cm}$ の間 隔で 12 株を 10 月 17 日に定植した. 基肥として緩効性肥料 （CDU 複合燐加安（15:15:15））を用い，各成分を株当た り $250 \mathrm{mg}$ 施用した。. 各試験区には, それぞれ 3 コンテナ を割り当てた，定植後最低 $15^{\circ} \mathrm{C}$ に加温したガラス温室で 栽培し，12月 11 日に昼温 $30^{\circ} \mathrm{C}$ 夜温 $15^{\circ} \mathrm{C}$ に制御した自然 光利用型ファイトトロン（エスペック（株）製 TAE-700） に移し，生育を揃えるために試験開始まで深夜 4 時間の電 照を行った. 未展開の $2 \sim 3$ 葉を開いて第 1 花蕾を確認し た 2003 年 2 月 4 日より (1) (8)の試験区の温度処理を開始し た（第 2 図）．前述のと抢り覆輪発現の乱れが生じる低温を 昼温 $20^{\circ} \mathrm{C}$ 夜温 $15^{\circ} \mathrm{C}$ （以下 $20 / 15^{\circ} \mathrm{C}$ と記述する）とし，覆 輪発現の乱れが生じない高温を昼温 $30^{\circ} \mathrm{C}$ 夜温 $15^{\circ} \mathrm{C}$ (以下 $30 / 15^{\circ} \mathrm{C}$ と記述する）とした。試験区(1)は，第 2 図のと拉 りファイトトロンに移した 12 月 11 日〜採花までの期間を $30 / 15^{\circ} \mathrm{C}$ とした. 一方，(2)〜8の試験区は，20/15 ${ }^{\circ} \mathrm{C}$ の遭遇 開始までを $30 / 15^{\circ} \mathrm{C}$ で管理した後，所定の期間を $20 / 15^{\circ} \mathrm{C}$ に遭遇させた，その後試験区(2)，(3)，(4)，(6)抢よび(7)は， 採花までの期間を $30 / 15^{\circ} \mathrm{C}$ で管理した. $20 / 15^{\circ} \mathrm{C}$ の低温遭遇 期間が覆輪の発現に及ぼす影響を明らかにするために，試 験開始からの $20 / 15^{\circ} \mathrm{C}$ の遭遇期間を試験区(2)は 2 週間, 試 験区(3)は 4 週間, 試験区(4)は 6 週間抽よび試験区(5)は採花 までとした。 $20 / 15^{\circ} \mathrm{C}$ の遭遇時期が覆輪発現に及ぼす影響 を明らかにするために，試験開始 $2 \sim 6$ 週後までの 4 週間 を 20/15C に遭遇した試験区(6) と試験開始 $4 \sim 6$ 週後まで の 2 週間を $20 / 15^{\circ} \mathrm{C}$ に遭遇した試験区(7)を設けた.さらに, 生育後半の日中は十分に換気を行い，硬く締まった切り花 を作る生産現場に近い条件が覆輪発現に及ぼす影響を明ら かにするために，試験開始 4 週後〜採花まで $20 / 15^{\circ} \mathrm{C}$ の低 温に遭遇した試験区88設けた。

なお，昼温の設定時間は一日のらち 7 時 30 分〜 17 時 30

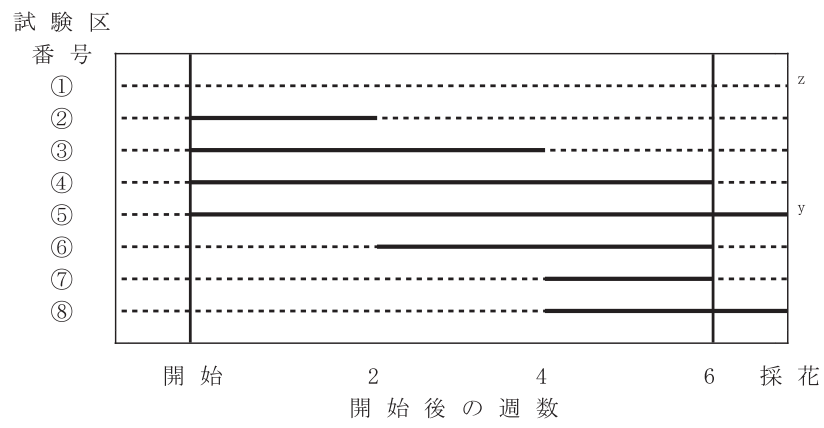

第 2 図各試験区の試験開始後の温度処理 z .....は昼温 $30^{\circ} \mathrm{C}$ 夜温 $15^{\circ} \mathrm{C}$ の期間 $\mathrm{y}$ — は昼温 $20^{\circ} \mathrm{C}$ 夜温 $15^{\circ} \mathrm{C}$ の期間

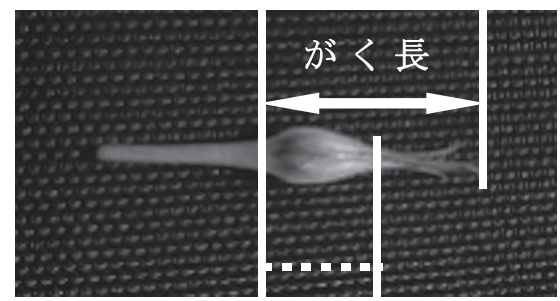

花 蕾 長

第 3 図 がく長と花弁の先端が見えない蕾の花蕾長 (点線部の 長さ)

分までの 10 時間，夜温の設定時間は 19 時 30 分〜 5 時 30 分までの 10 時間とし, 温度の上げ下げにそれぞれ 2 時間を 設けた。各試験区に割り当てた 3 コンテナの 36 株のらち, がく長 (がく基部〜がく先端までの長さ, 第 3 図）が $10 \mathrm{~mm}$ 前後の $21 \sim 26$ 株を調査対象とした。試験区間に肥料や光 条件の影響による差が生じないようにするため非調査対象 株もそのまま栽培した。

\section{2. 調査方法}

第 4 図に示したとおり，主茎の頂花を第 1 花，1 次側枝 の頂花を第 2 花，2 次側枝の頂花を第 3 花，3 次側枝の頂花 を第 4 花とした。試験開始時に主茥の頂花である第 1 花の がく長（がく基部〜がく先端までの長さ，第 3 図）が 8,11 および $16 \mathrm{~mm}$ の 3 株について, 第 1 花着生節とその下の二

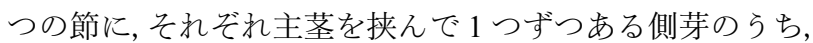
各節とも伸び始めている側芽の花芽の分化状況を調査し た. 花芽の分化ステージは，小林（2003）の記述に従った.

試験開始から $20 / 15^{\circ} \mathrm{C}$ に遭遇した試験区(2)，(3)打よび(4) については $20 / 15^{\circ} \mathrm{C}$ の遭遇終了後に, 試験開始 2 週もしく は 4 週後から $20 / 15^{\circ} \mathrm{C}$ に遭遇した試験区(6)，(7)おび8に ついては, $20 / 15^{\circ} \mathrm{C}$ の遭遇開始時に第 $1 \sim 4$ 花の花蕾長 (が く基部〜花弁先端までの長さ，第 3 図）を測定した．花弁 の先端が見えずに測定できない場合は，第 3 図に示した点 線部の長さを測定した。なお，第 4 花は測定が難しい試験 区もあったので，各株の測定可能な蕾の長い方から 3 蕾の 平均とした. 


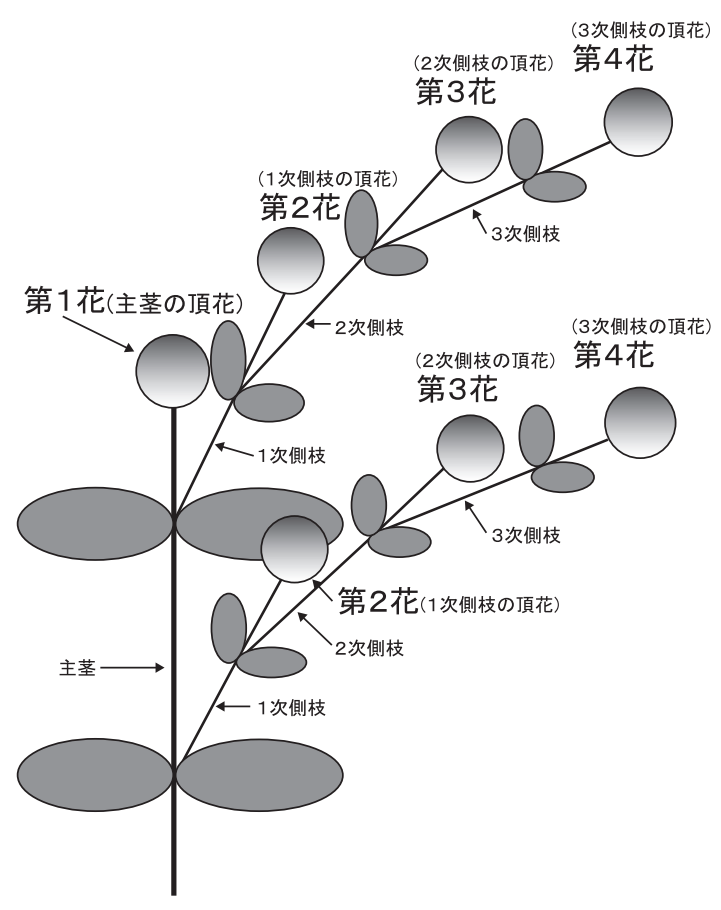

第 4 図トルコギキョウの花序略図

第 3 花が咲きそろった頃採花し, 供試株の切り花調査を 行った. 開花しているすべての花から 5 枚の花弁のらち着 色割合が平均的な 1 枚の花弁を第 $1 \sim 4$ 花の小花の次数別 に採取し，カラーコピー機（(株）リコー製）で花弁の向軸 側を複写した。 それぞれの花弁の複写について，花弁の下 端〜先端までの花弁長と花弁幅を測定し, 花弁の平均長幅 比を求めた．また，コピー用紙に複写した花弁を切り抜き， 花弁を着色部と白色部に切り分け，それぞれの面積を葉面
積計（林電工製 AAM-9）で測定して，各試験区の花弁の平 均着色割合と第 $1 \sim 4$ 花の次数別の花弁の平均着色割合を 求めた. 花弁の平均着色割合の有意差の検定は, 各花弁の 着色割合をアークサイン変換後さらに対数変換した值を用 いて Tukeyの多重比較を行った.

\section{結果}

\section{1. 試験開始時の花芽の分化状況と試験開始後最初の変温 時の第 $1 \sim 4$ 花の花蕾長}

試験開始時に第 1 花のがく長（がく基部〜がく先端まで の長さ, 第 3 図) が $8 \sim 16 \mathrm{~mm}$ の 3 株の第 1 花は, いずれ れも雌ずい形成期であった (第 1 表). 第 2 花は花弁形成〜 雌ずい形成期に, 第 3 花は茎頂膨大〜花弁形成期に, 第 4 花は茥頂膨大〜がく片形成期にあった.

試験開始後 $20 / 15^{\circ} \mathrm{C} て ゙ 2$ 週間を経過した試験区(2)の第 1 $\sim 4$ 花の花蕾長（がく基部～花弁先端までの長さ, 第 3 図) は，それぞれ 10.5, $5.4 ， 2.8,2.0 \mathrm{~mm}$ であったのに対し， $30 / 15^{\circ} \mathrm{C}$ で 2 週間経過した試験区(6)の第 $1 \sim 4$ 花の花蕾長 は，それぞれ $13.9 ， 8.0 ， 3.5,2.4 \mathrm{~mm}$ とやや大きかった（第 2 表)。試験開始後 $20 / 15^{\circ} \mathrm{C}$ で 4 週間を経過した試験区(3)の 第 1 ～ 4 花の花蕾長は，それぞれ20.4，11.1，7.2，4.8 mm であったのに対し， $30 / 15^{\circ} \mathrm{C} て ゙ 4$ 週間経過した試験区(7) と 8)の第 $1 \sim 4$ 花の花蕾長は, それぞれ 31.8 と $36.8 \mathrm{~mm}, 20.5$ と $18.2 \mathrm{~mm}, 12.5$ と $11.1 \mathrm{~mm}, 8.6$ と $7.1 \mathrm{~mm}$ であり，1.5〜 2 倍大きかった. $20 / 15^{\circ} \mathrm{C} て ゙ 6$ 週間経過した試験区(4)の第 1 〜 4 花の花蕾長は，それぞれ 32.9, 20.8，12.8，9.6 mm で あり, 試験開始から $30 / 15^{\circ} \mathrm{C} て ゙ 4$ 週間経過した試験区(7)や (8)とほぼ同等であった.

第 1 表 第 $1 \sim 4$ 花の花芽分化状況

\begin{tabular}{|c|c|c|c|c|}
\hline 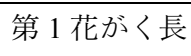 & 第 1 花 & 第 2 花 & 第 3 花 & 第 4 花 \\
\hline $8 \mathrm{~mm}$ & 雌ずい形成 $(1)^{z}$ & 花弁形成〜雄ずい形成（3） & 茥頂膨大～がく片形成（3） & 茥頂膨大（3） \\
\hline $11 \mathrm{~mm}$ & 雌ずい形成（1） & がく片形成〜雄ずい形成（3） & 茎頂膨大～花弁形成（3） & 茎頂膨大～がく片形成（3） \\
\hline $16 \mathrm{~mm}$ & 雌ずい形成（1） & 花弁形成～雌ずい形成（3） & がく片形成～花弁形成（3） & 茎頂膨大～がく片形成（3） \\
\hline
\end{tabular}

$\mathrm{z}$ ( ）内の数字は調査点数を示す

第 2 表 試験開始後最初の変温時の第 $1 \sim 4$ 花の花蕾長

\begin{tabular}{|c|c|c|c|c|}
\hline \multirow{2}{*}{ 試験区番号 ${ }^{z}$} & \multicolumn{4}{|c|}{ 花蕾長 ${ }^{y}$ （mm） } \\
\hline & 第 1 花 & 第 2 花 & 第 3 花 & 第 4 花 $^{x}$ \\
\hline (2) & $10.5 \pm 2.3(22)^{\mathrm{w}}$ & $5.4 \pm 2.3 \quad(77)$ & $2.8 \pm 1.4(80)$ & $2.0 \pm 0.8$ \\
\hline (3) & $20.4 \pm 8.2$ & $11.1 \pm 4.8 \quad(75)$ & $7.2 \pm 3.3 \quad(89)$ & $4.8 \pm 2.3 \quad(56)$ \\
\hline (4) & $32.9 \pm 9.6$ & $20.8 \pm 9.3$ & $12.8 \pm 6.6$ & $9.6 \pm 4.6 \quad(69)$ \\
\hline (6) & $13.9 \pm 3.8$ & $8.0 \pm 3.8$ & $3.5 \pm 1.9$ & $2.4 \pm 1.5 \quad(56)$ \\
\hline (7) & $31.8 \pm 12.0$ & $20.5 \pm 11.7$ & $12.5 \pm 7.9$ & $8.6 \pm 5.5 \quad(57)$ \\
\hline (8) & $36.8 \pm 10.8$ & $18.2 \pm 8.2$ & $11.1 \pm 4.9$ & $7.1 \pm 3.3$ \\
\hline
\end{tabular}

\footnotetext{
$\mathrm{z}$ 各試験区の概要は第 2 図のとおり

$\mathrm{y}$ 花蕾長は第 3 図参照, 平均値 \pm 標準偏差

$\mathrm{x}$ 第 4 花は各株の測定可能な蕾の大きい方から 3 蕾の平均

w ( ) 内の数字は調査点数
} 


\section{2. $20 / 15^{\circ} \mathrm{C}$ への遭遇が生育，切り花品質に及ぼす影響}

$20 / 15^{\circ} \mathrm{C}$ に遭遇しない試験区(1)の試験開始〜採花までの 日数は 51 日で最も早かった (第 3 表). $20 / 15^{\circ} \mathrm{C} に 2 \sim 4$ 週 間遭遇した試験区(2)，(3)，(6)よび(7)の採花までの日数は, 試験区(1)より 7〜 11 日遅れた. $20 / 15^{\circ} \mathrm{C} に 6$ 週間以上遭遇 した試験区(4)，(5)打よび(8)の採花までの日数は，試験区(1) より $15 \sim 26$ 日遅れた. 切り花長と切り花重は, 昼温 $20^{\circ} \mathrm{C}$ に遭遇しない試験区(1)で最も小さくなった。 その他の試験 区間には，大きな差はみられなかった，花数は，試験開始 後長期間 $30 / 15^{\circ} \mathrm{C}$ に遭遇した試験区で少なく, $20 / 15^{\circ} \mathrm{C}$ の遭 遇期間が長い試験区で多い傾向にあった，花弁面積は，20/ $15^{\circ} \mathrm{C}$ に遭遇しない試験区(1)が $12.2 \mathrm{~cm}^{2}$ と最も小さかった. 一方，試験開始〜採花まで $20 / 15^{\circ} \mathrm{C}$ に遭遇した試験区(5)の 花弁面積は $15.8 \mathrm{~cm}^{2}$ と最も大きく, 次に $20 / 15^{\circ} \mathrm{C}$ に 6 週間 遭遇した試験区(4)が $14.8 \mathrm{~cm}^{2}$ と大きかった，他の試験区の 花弁面積は $14 \mathrm{~cm}^{2}$ 程度であった. 花弁の長幅比は, 試験開 始 4 週後〜採花まで $20 / 15^{\circ} \mathrm{C}$ に遭遇した試験区88除いて, $20 / 15^{\circ} \mathrm{C}$ の遭遇時期には関係なく遭遇期間が長い汪ぞ小さ くなる傾向を示した. 試験開始から 6 週間 $20 / 15^{\circ} \mathrm{C}$ に遭遇 した試験区(4)の長幅比は，1.40 と最も小さい值であった.
20/15 $\mathrm{C}$ に遭遇しない試験区(1) と開始 4 週後〜採花まで $20 /$ $15^{\circ} \mathrm{C}$ に遭遇した試験区8)の長幅比は 1.61 と最も大きい值 を示した。

\section{3. $20 / 15^{\circ} \mathrm{C}$ の遭遇期間が花弁の着色割合に及ぼす影響}

$20 / 15^{\circ} \mathrm{C}$ に遭遇しない試験区(1)の花弁の平均着色割合は, $13.5 \%$ と最も小さく，10\%未満の着色割合の花弁が $35.2 \%$ を占めた (第 4 表)，試験開始から $20 / 15^{\circ} \mathrm{C}$ にわずか 2 週間 遭遇した試験区(2)の花弁の平均着色割合は，39\%と有意に 高くなり，40\%以上着色した花弁が 28.8\%あった.さらに， 試験開始からの $20 / 15^{\circ} \mathrm{C}$ の遭遇期間が長いほど花弁の平均 着色割合は高くなった（第 4 表，試験区(2)，(3)，(4)打よび (5)．また，40\%以上着色した花弁の頻度も遭遇期間が長い ほど高くなった． $20 / 15^{\circ} \mathrm{C}$ に 6 週間以上遭遇した試験区(4) と(5)は，90\%以上着色した花弁が約 70\%を占めた.

\section{4. $20 / 15^{\circ} \mathrm{C}$ の遭遇時期が花弁の着色割合に及ぼす影響}

試験開始から 2 週間もしくは 4 週間 $20 / 15^{\circ} \mathrm{C}$ に遭遇した 試験区(2) と(3)の花弁の平均着色割合は，試験開始 2 週後か ら 4 週間もしくは 4 週後から 2 週間 $20 / 15^{\circ} \mathrm{C}$ に遭遇した試 験区(6) と(7)の花弁の平均着色割合に比べて有意に高かった (第 4 表)。試験開始 4 週後〜採花まで $20 / 15^{\circ} \mathrm{C}$ に遭遇した

第 3 表 低温遭遇期間と時期が切り花品質に及ぼす影響

\begin{tabular}{|c|c|c|c|c|c|c|c|c|c|}
\hline $\begin{array}{l}\text { 試験区 } \\
\text { 番号 }\end{array}$ & $\begin{array}{l}\text { 供試 } \\
\text { 株数 }\end{array}$ & $\begin{array}{l}\text { 採花までの } \\
\text { 日数 }{ }^{\mathrm{z}} \text { (日) }\end{array}$ & $\begin{array}{c}\text { 切り花長 } \\
(\mathrm{cm})\end{array}$ & $\begin{array}{c}\text { 切り花重 } \\
(\mathrm{g})\end{array}$ & $\begin{array}{l}\text { 花数 }{ }^{\mathrm{y}} \\
\text { (個／株) }\end{array}$ & $\begin{array}{c}\text { 花弁面積 } \\
\left(\mathrm{cm}^{2}\right)\end{array}$ & $\begin{array}{c}\text { 花弁長 } \\
(\mathrm{cm})\end{array}$ & $\begin{array}{c}\text { 花弁幅 } \\
(\mathrm{cm})\end{array}$ & $\begin{array}{l}\text { 長幅比 } \\
\text { (長 / 幅) }\end{array}$ \\
\hline (1) $x$ & 22 & 51 & $124.6 \mathrm{a}^{\mathrm{w}}$ & $77.5 \mathrm{a}$ & $18.2 \mathrm{a}$ & $12.2 \mathrm{a}$ & 5.92 & 3.69 & $1.61 \mathrm{a}$ \\
\hline (2) & 22 & 58 & $144.1 \mathrm{bc}$ & $101.8 \mathrm{~b}$ & $23.1 \mathrm{abc}$ & $14.3 \mathrm{~b}$ & 6.24 & 3.99 & $1.56 \mathrm{~b}$ \\
\hline (3) & 23 & 62 & $140.7 \mathrm{bc}$ & $94.3 \mathrm{ab}$ & $24.2 \mathrm{bc}$ & $14.1 \mathrm{~b}$ & 6.08 & 4.08 & $1.50 \mathrm{c}$ \\
\hline (4) & 24 & 66 & $139.3 \mathrm{bc}$ & $104.3 \mathrm{~b}$ & $26.0 \mathrm{c}$ & $14.8 \mathrm{bc}$ & 6.01 & 4.29 & $1.40 \mathrm{~d}$ \\
\hline (5) & 25 & 77 & $142.1 \mathrm{bc}$ & $106.7 \mathrm{~b}$ & $23.0 \mathrm{abc}$ & $15.8 \mathrm{c}$ & 6.29 & 4.48 & $1.41 \mathrm{~d}$ \\
\hline (6) & 22 & 59 & $145.2 \mathrm{c}$ & $108.0 \mathrm{~b}$ & $24.8 \mathrm{bc}$ & $14.2 \mathrm{~b}$ & 6.09 & 4.12 & $1.48 \mathrm{c}$ \\
\hline (7) & 21 & 59 & $136.0 \mathrm{~b}$ & $91.0 \mathrm{ab}$ & $20.2 \mathrm{ab}$ & $14.2 \mathrm{~b}$ & 6.19 & 4.00 & $1.55 \mathrm{~b}$ \\
\hline (8) & 26 & 76 & $137.0 \mathrm{bc}$ & $99.6 \mathrm{~b}$ & $19.1 \mathrm{a}$ & $13.5 \mathrm{~b}$ & 6.23 & 3.89 & $1.61 \mathrm{a}$ \\
\hline
\end{tabular}

${ }^{\mathrm{z}}$ 温度処理を開始した 2 月 4 日〜採花までの日数

$\mathrm{y}$ 花数は蕾を含む全花数

$\mathrm{x}$ 各試験区の概要は第 2 図のと抏り

w 同符号間に Tukey 法で 5\%水準の有意差なし

第 4 表 低温遭遇期間と時期が花弁の着色割合の平均値と頻度分布に及ぼす影響

\begin{tabular}{|c|c|c|c|c|c|c|c|c|c|c|c|}
\hline \multirow{2}{*}{$\begin{array}{c}\text { 試験区 } \\
\text { 番号 }\end{array}$} & \multirow{2}{*}{$\begin{array}{l}\text { 花弁の平均 } \mathrm{z} \\
\text { 着色割合 }(\%)\end{array}$} & \multicolumn{10}{|c|}{ 花弁の着色割合の頻度（\%) } \\
\hline & & $\begin{array}{c}0 \text { 以上 } \\
10 \text { 末満 }\end{array}$ & $\begin{array}{l}10 \text { 以上 } \\
20 \text { 末満 }\end{array}$ & $\begin{array}{l}20 \text { 以上 } \\
30 \text { 末満 }\end{array}$ & $\begin{array}{l}30 \text { 以上 } \\
40 \text { 末満 }\end{array}$ & $\begin{array}{l}40 \text { 以上 } \\
50 \text { 末満 }\end{array}$ & $\begin{array}{l}50 \text { 以上 } \\
60 \text { 末満 }\end{array}$ & $\begin{array}{l}60 \text { 以上 } \\
70 \text { 末満 }\end{array}$ & $\begin{array}{l}70 \text { 以上 } \\
80 \text { 末満 }\end{array}$ & $\begin{array}{l}80 \text { 以上 } \\
90 \text { 末満 }\end{array}$ & $\begin{array}{c}90 \text { 以上 } \\
100\end{array}$ \\
\hline (1) ${ }^{y}$ & $13.5 \mathrm{a}^{\mathrm{x}}(201)^{\mathrm{w}}$ & 35.2 & 52.6 & 9.8 & 1.5 & 0.9 & & & & & \\
\hline (2) & 39.0 c (218) & & 15.5 & 34.7 & 21.0 & 6.9 & 4.1 & 3.2 & 4.1 & 2.3 & 8.2 \\
\hline (3) & $72.6 \mathrm{~d}(193)$ & 0.5 & 2.6 & 12.4 & 6.7 & 4.1 & 7.8 & 4.7 & 8.8 & 7.8 & 44.6 \\
\hline (4) & 88.0 e (192) & & & 2.6 & 3.7 & 3.1 & 2.1 & 4.2 & 7.8 & 8.3 & 68.2 \\
\hline (5) & $86.0 \mathrm{e}(218)$ & & & 1.9 & 9.2 & 3.2 & 6.4 & 0.9 & 3.2 & 3.2 & 72.0 \\
\hline (6) & $26.0 \mathrm{~b} \quad(165)$ & 3.6 & 30.9 & 38.8 & 15.8 & 6.7 & 2.4 & & 0.6 & & 1.2 \\
\hline (7) & $22.7 \mathrm{~b} \quad(173)$ & 1.1 & 37.0 & 45.1 & 13.9 & 2.9 & & & & & \\
\hline (8) & $20.0 \mathrm{~b} \quad(314)$ & & 52.9 & 39.5 & 7.6 & & & & & & \\
\hline
\end{tabular}

${ }^{\mathrm{z}}$ 開花している第 $1 \sim 4$ 花のすべての花弁の平均

y 各試験区の概要は第 2 図のと抢り

$\mathrm{x}$ 同符号間に Tukey 法で 5\%水準の有意差なし

w（）内は調査花弁数 
試験区8の花弁の平均着色割合は $20.0 \%$ あり, 試験開始 4 週後から 2 週間 $20 / 15^{\circ} \mathrm{C}$ に遭遇した試験区(7)の平均着色 割合と比べて有意差は認められなかった。

\section{5. $20 / 15^{\circ} \mathrm{C}$ への遭遇が異なる着生位置の小花の着色割合に 及ぼす影響}

第 1 花の花弁の平均着色割合は, $20 / 15^{\circ} \mathrm{C}$ に遭遇しない 試験区(1)の $17.8 \%$ が最も小さかった (第 5 図). 試験開始か ら 20/15 ${ }^{\circ} \mathrm{C} 2 \sim 6$ 週間遭遇した試験区(2), (3)抒よび(4)の 第 1 花の平均着色割合は, 遭遇期間が長いほど高くなった. 試験開始 2 週〜 6 週後まで $20 / 15^{\circ} \mathrm{C}$ に遭遇した試験区(6)の 第 1 花の花弁の平均着色割合は, 試験区(1)よりも高かった. 試験開始 4 週〜 6 週後または採花まで $20 / 15^{\circ} \mathrm{C}$ に遭遇した 試験区(7) と (8)の第 1 花の花弁の平均着色割合は, 試験区(1) よりやや高くなった.

第 $2 \sim 4$ 花の花弁の平均着色割合も, $20 / 15^{\circ} \mathrm{C}$ に遭遇し ない試験区(1)の着色割合が $14.2 \sim 11.7 \%$ と最も小さかった (第 5 図). 試験開始から $20 / 15^{\circ} \mathrm{C} に 2 \sim 6$ 週間遭遇した試 験区(2), (3)㧍よび(4)の第 $2 \sim 4$ 花の花弁の平均着色割合も, 遭遇期間が長いほど高くなった. $20 / 15^{\circ} \mathrm{C}$ に 6 週間以上遭 遇した試験区(4)と(5)では, 第 $1 \sim 4$ 花の順に花弁の平均着 色割合が高くなった．特に，花弁形成期以前から $20 / 15^{\circ} \mathrm{C}$ に遭遇した第 3 花と第 4 花は, 花弁の $90 \%$ 以上が着色した (第 1 表，第 5 図).

試験開始 2 週もしくは 4 週〜 6 週後もしくは採花まで $20 /$ $15^{\circ} \mathrm{C}$ に遭遇した試験区(6)，(7)打よび(8)の第 $2 \sim 4$ 花の花弁 の平均着色割合は, 試験区(1)の第 $2 \sim 4$ 花と比べて高くなっ た. 試験開始 4 週〜 6 週後もしくは採花まで $20 / 15^{\circ} \mathrm{C}$ に遭

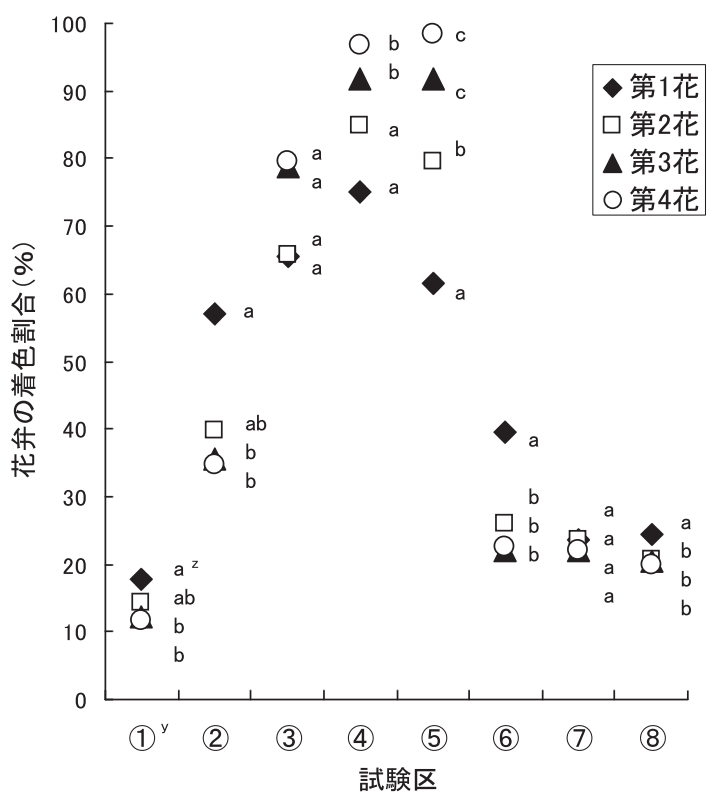

第 5 図 第 $1 \sim 4$ 花の花弁の着色割合に及ぼす低温遭遇期間 と時期の影響

$\mathrm{z}$ 異なる着生位置にある小花間について，試験区内の同 符号間に Tukey 法で 5\%水準の有意差なし

$\mathrm{y}$ 各試験区の概要は第 2 図のとおり
遇した試験区(7) と 8)の第 $2 ４$ 花の花弁の平均着色割合に は，大きな差は認められなかった。

$20 / 15^{\circ} \mathrm{C}$ に遭遇しない試験区(1)の第 1 花の花弁の平均着 色割合は，試験区(1)の第 $3 \sim 4$ 花と比べて有意に高かった (第 5 図). 試験開始 2 週後から 4 週間を $20 / 15^{\circ} \mathrm{C}$ 飞遭遇乙 た試験区(6)の第 1 花の平均着色割合も, 試験区(6)の第 2 4 花と比べて有意に高かった。 また，試験開始 4 週後〜採 花まで $20 / 15^{\circ} \mathrm{C}$ に遭遇した試験区 8の第 1 花の花弁の平均 着色割合も, 試験区(8)の第2〜4花と比べて有意に高かった.

\section{考察}

\section{1. $20 / 15^{\circ} \mathrm{C}$ の低温遭遇期間が覆輪発現に及ぼす影響}

生産現場において生産者が直接目視で確認できる技術の 確立を前提としたため，未展開葉を $2 \sim 3$ 枚開いた第 1 花 蕾の確認時, すなわち, 第 1 花の雌ずい形成期を起点とし た $20 / 15^{\circ} \mathrm{C}$ の遭遇期間が覆輪発現に及洼す影響を調べた。 その結果，試験開始直後から $20 / 15^{\circ} \mathrm{C}$ にわずか 2 週間，そ して試験開始〜採花までの間に $20^{\circ} \mathrm{C}$ 以下に 820 時間遭遇 すると覆輪発現が乱れ，花弁の周辺や全体が着色した花弁 が生じ，花弁の平均着色割合が 39\%に高まった（第 2 図, 第 4 表の試験区(2))。また， $20 / 15^{\circ} \mathrm{C}$ の遭遇期間が 6 週間, 試験開始〜採花までの間に $20^{\circ} \mathrm{C}$ 以下の遭遇時間が 1,272 時 間では, 花弁の平均着色割合が約 90\%に達した。この結果 は，採花日から遡った 60 日間の $20^{\circ} \mathrm{C}$ 未満の積算遭遇時間 が 800 時間を上回ると直線的に花弁の着色割合が高まった ことを報告した渡辺（2006）の試験に打いて，“キャンディ マリン’と ‘ネイルピーチネオ' の花弁の平均着色割合が, 820 時間と 1,270 時間の積算遭遇時間で，各々 $20 \sim 30 \%$ と 78 ～85\%となった結果とほぼ一致した. 本研究の結果から は, $20 / 15^{\circ} \mathrm{C}$ 遭遇後の $30 / 15^{\circ} \mathrm{C}$ への遭遇に花弁の着色割合を わずかでも高める効果があるのか，もしくは覆輪発現の乱 れの進行を完全に抑制する効果があるのかは不明である. しかし, 本研究により第 1 花の雌ずい形成期を起点とした $20 / 15^{\circ} \mathrm{C}$ の低温遭遇期間と花弁の着色割合の関係が明確に 示された．一方， $20 / 15^{\circ} \mathrm{C}$ の遭遇期間が長い注ど花弁の長 幅比が小さくなった (第 3 表)。これも覆輪発現の乱れと関 連する可能性が考光られるので，今後詳細な検討が必要と 思わ机る。

\section{2. $20 / 15^{\circ} \mathrm{C}$ の低温遭遇時期が覆輪発現と切り花品質に及ぼ す影響}

トルコギキョウの覆輪発現に及ぼす低温遭遇時期の影響 を調べた報告は汪とんぞない，そこで，本報告では，20/ $15^{\circ} \mathrm{C}$ の遭遇期間は同じでも，第 1 花の雌ずい形成期を起点 とした遭遇時期が異なる試験区を設け, $20 / 15^{\circ} \mathrm{C}$ の遭遇時期 が覆輪の発現に及ぼす影響を調べた。その結果， $20 / 15^{\circ} \mathrm{C} の$ 遭遇期間は同じでも, 第 1 花の雌ずい形成期から $20 / 15^{\circ} \mathrm{C}$ に 遭遇した方が，花弁の着色割合が有意に高いことが示され た (第 4 表)。しかも，第 1 花の雌ずい形成期から 4 週間を $30 / 15^{\circ} \mathrm{C}$ で経過すれば，以後採花まで $20 / 15^{\circ} \mathrm{C}$ に遭遇しても 
覆輪発現に大きな影響を及ぼさないことも明らかになった (第 4 表)。また，この場合，すべての期間を $30 / 15^{\circ} \mathrm{C} て ゙$ 経 過した時と比べて, 採花時期は遅れるものの, 花弁が大き くなるとともに，切り花長と切り花重も大きくなるなど切 り花品質が向上し, 有効な管理方法と考光られた(第 3 表).

第 1 花の雌ずい形成期から $30 / 15^{\circ} \mathrm{C}$ で 4 週間経過した後 に2 週間（試験区(7)）もしくは採花まで（試験区(8)）20/ $15^{\circ} \mathrm{C}$ に遭遇した花弁の着色割合は, すべての期間を $30 / 15^{\circ} \mathrm{C}$ で経過した場合（試験区(1)）と比べてやや高かった（第 4 表)。すべての期間を $30 / 15^{\circ} \mathrm{C} て ゙$ 経過した（試験区(1)）花弁 面積と着色面積を 1 とした場合, $30 / 15^{\circ} \mathrm{C}$ で 4 週間経過し た後に 2 週間もしくは採花まで $20 / 15^{\circ} \mathrm{C}$ に遭遇した（試験 区(7)と（8)）花弁面積は $1.1 １ .2$ 倍であったのに対し, 着色 面積は $1.6 〜 2.0$ 倍であった (第 3,4 表).このことは, 第 1 花の雌ずい形成期以降 $30 / 15^{\circ} \mathrm{C}$ で 4 週間経過した後の $20 /$ $15^{\circ} \mathrm{C}$ へ遭遇には, 花弁面積をやや大きくするとともに, 花弁面積の拡大率以上飞覆輪部分を大きくする効果がある と考光られた. トルコギキョウの覆輪品種では, 花弁基部 の白色部分に扮いて，アントシアニンの生合成遺伝子のう ちカルコンシンターゼ遺伝子の発現が抑制されていること が知られている (福田ら, 2003)。しかし, 低温遭遇とアン トシアニンの生合成遺伝子の花弁内の部位特異的な発現と の関係については今後の詳細な検討が待たれる.

\section{3. 花弁の着色割合と花芽の分化ステージおよび着生位置 との関係}

第 1 花の雌ずい形成期〜採花まで $20 / 15^{\circ} \mathrm{C}$ に遭遇すると, 花弁の着色割合は, 第 $1 \sim 4$ 花の順に高くなった（第 5 図 の試験区(5)，特に, 花弁形成期以前から $20 / 15^{\circ} \mathrm{C}$ 飞 6 週間 以上遭遇した第 $3 \sim 4$ 花は花弁の $90 \%$ 以上が着色した（第 1 表, 第 5 図)。このことから, 分化ステージの若い花芽の 方が, $20 / 15^{\circ} \mathrm{C}$ の低温の感受性が高いと考光られた，従っ て, 覆輪発現の乱孔を抑制するためには, 第 1 花の分化ス テージが雌ずい形成期に達する以前の高温管理も重要であ ると考兄られる。一方, 分化ステージの若い花芽の方が, 低温の感受性が高いのであれば，第 1 花の雌ずい形成期か ら 2 週間を $30 / 15^{\circ} \mathrm{C}$ で経過した後 $20 / 15^{\circ} \mathrm{C}$ に遭遇した場合 (試験区(6)， $20 / 15^{\circ} \mathrm{C}$ の低温の影響は，第 1 花よりも若い 花芽に及び, 最初の変温時の花蕾長（がく基部～花弁先端 までの長さ）が $8 \sim 2.4 \mathrm{~mm}$ と小さい第 $2 \sim 4$ 花に現れる ことが予想される (第 2 表). しかし, 第 1 花の平均着色割 合は約 40\%であり, 第 $2 \sim 4$ 花の $27 \sim 20 \%$ と比べて有意 に高かった（第 5 図の試験区(6)）。これらのことから，20/ $15^{\circ} \mathrm{C}$ の低温遭遇によって生じる覆輪発現の乱れには, 花芽 の分化ステージの老若の他に別の要因が関与している可能 性が示唆された，さらに，この他にも第 1 花の平均着色割 合が高く現れた例がある. 第 1 花の雌ずい形成期から 4 週 間を $30 / 15^{\circ} \mathrm{C}$ で経過した後, 採花まで $20 / 15^{\circ} \mathrm{C}$ に遭遇した 第 1 花の平均着色割合も第 $2 \sim 4$ 花と比べて有意に高かっ た（第 5 図の試験区 (8)， $20 / 15^{\circ} \mathrm{C}$ に遭遇しない第 1 花の花
弁の平均着色割合も，第 $3 \sim 4$ 花と比べて有意に高かった (第 5 図の試験区(1)）。これらの結果から，第 1 花には，花 弁の着色割合が高くなりやすい何らかの要因があると考光 られる。福田ら（2007）は, 施肥量が花弁の着色割合に及 ぼす影響を調査し，水のみを与えた試験区ょりも，窒素 $150 \mathrm{ppm}$ を含む液肥を与えた試験区の方が花弁の着色割合 が高くなることを見いだした。そして，これを節数の増加 と関連付け，第 1 花着生節が高く栄養生長が旺盛となる環 境条件に打いて花弁の着色割合が高くなると報告してい る. 笠原（1991）は，ッバキの覆輪品種である ‘玉の浦” について，株が小さく栄養状態が良い間は単色の花を咲か せるが，樹勢が落ち着くと本来の覆輪の花を咲かせるよう になるとしている．主茎の頂花である第 1 花は，栄養生長 から生殖生長に切り替わる間にある，そのため，栄養生長 が旺盛な場合，第 1 花の着色割合は，第 $2 \sim 4$ 花よりも高 く現れやすいのではないかと考光られた.

以上のことから，第 1 花の雌ずい形成期からわずか 2 週 間でも $20 / 15^{\circ} \mathrm{C}$ の低温に遭遇すると覆輪の発現が乱れ, 着 色割合の高い花弁が生じることが明らかになった. 従って, 第 1 花の雌ずい形成期まで， $30 / 15^{\circ} \mathrm{C}$ の高温で管理した場 合，覆輪発現が乱れないようにするには，そのまま 4 週間 程度 $30 / 15^{\circ} \mathrm{C}$ の高温で継続して管理すれば，以後は低温で 管理しても覆輪発現は乱れず, 花弁が大きくかつ切り花長 と切り花重も大きい良品生産に役立つと考光られた. また， 覆輪発現が乱れる低温遭遇期間と時期や生育ステージが明 らかになったことによって，低温下でも覆輪の発現が乱れ ない品種の育成に役立つと考光られた.

\section{摘 要}

トルコギキョウ覆輪品種の花弁の着色割合に及ぼす 20/ $15^{\circ} \mathrm{C}$ (昼 / 夜温) の遭遇期間と時期の影響について検討し た. 温度処理は第 1 花の雌ずい形成期から開始した。 その 結果以下のことを見いだした． $20 / 15^{\circ} \mathrm{C}$ の遭遇期間の影響 そついてみると， $20 / 15^{\circ} \mathrm{C}$ の遭遇期間が 6 週までは，遭遇 期間が長いほど花弁の着色割合は有意に高くなった．20/ $15^{\circ} \mathrm{C}$ の遭遇時期の影響についてみると，20/15 $\mathrm{C}$ に同じ期 間遭遇しても，第 1 花の雌ずい形成期から遭遇した方が, 第 1 花の雌ずい形成期の 2 週もしくは 4 週後から遭遇した 場合と比べて花弁の着色割合が有意に高くなった。 また， 第 1 花の雌ずい形成期から 4 週間を $30 / 15^{\circ} \mathrm{C}$ で経過すると, 以後 $20 / 15^{\circ} \mathrm{C}$ に遭遇しても， $40 \%$ 以上着色した花弁は少な く, 覆輪の発現は安定していた。 また, この場合, すべて の期間を $30 / 15^{\circ} \mathrm{C}$ で経過した時と比べて，花弁が大きくな るとともに, 切り花長と切り花重も大きくなり切り花品質 も優孔た. 従って, 第 1 花の雌ずい形成期まで, $30 / 15^{\circ} \mathrm{C}$ 程 度で管理した場合, 覆輪発現が乱孔ないようにするには, そのまま 4 週間程度 $30 / 15^{\circ} \mathrm{C} て ゙$ 継続して管理すれば，以後 は低温で管理しても覆輪の発現は乱れず，良品生産に役立 つと考えられた。 


\section{引用文献}

吾妻浅男・高野恵子. 1996. トルコギキョウの開花調節に 関する研究 (第 2 報). 冷房あるいは夜冷育苗による冬 〜早春出し栽培. 高知農技七研報. 5: 58-65.

福田直子・中山真義. 2008. 温度条件がトルコギキョウ覆 輪花弁の着色面積率に及ぼす影響. 園学研. 7: 531-536. 福田直子・中山真義・牛尾亜由子. 2007. トルコギキョウ の覆輪着色面積率に及ぼす施肥量と日較差の影響. 園 学研. 6 (別2): 345 .

福田直子・大宮あけみ・伊藤佳央・小関良宏・野田尚信・ 菅野善明・鈴木正彦・中山真義. 2003. トルコギキョ ウ覆輪着色面積率に及洼す環境要因の影響解析. 園学 雑. 74 (別 2): 506.

福田直子・大澤 良・吉岡洋輔・中山真義. 2005. トルコ ギキョウに打将覆輪安定性の数量化による品種間変 異の評価. 園学研. 4: 265-269.

速水正弘. 2003. 静岡県に打的作型と栽培技術. p. 247252. 大川 清編著. 実践花き園芸技術トルコギキョ ウ. 誠文堂新光社. 東京.
笠原喜知治. 1991. 複色花の原因と発現機構. p. 49-57. バ イオホルティ7. 誠文堂新光社. 東京.

小林泰夫. 2003. 冷房育苗による秋抒よび冬切り栽培. p. 169-181. 大川 清編著. 実践花き園芸技術トルコギ キョウ. 誠文堂新光社. 東京.

諸富保司. 2003. 大分県に打战型と栽培技術. p. 263272. 大川 清編著. 実践花き園芸技術トルコギキョ ウ. 誠文堂新光社. 東京.

大川 清・山口繁雄・三好 学・山崎 文. 1996. トルコ ギキョウのロゼット苗の低温処理による促成栽培. 生 環調. 34: 45-52.

渡辺 功. 2000. トルコギキョウ覆輪品種の花色発現に及 ぼす昼温の影響. 2000. 園学九研集. 8: 91.

渡辺 功. 2003. 熊本県に扬ける作型と栽培技術. p. 273277. 大川 清編著. 実践花き園芸技術トルコギキョ ウ. 誠文堂新光社. 東京.

渡辺 功. 2006. トルコギキョウ覆輪品種の花弁の着色割 合の季節変動. 園学研. 5: 409-413.

山口 隆. 1991. トルコギキョウの切り花生産の現状と問 題点（1）. 農及園. 66: 309-316. 